\section{Dr. Matteson and Ms Crowson reply}

\section{To the Editor:}

We thank Drs. Grzybowski and Sak for their interest in our article ${ }^{1}$. They address an introductory background remark about the erythrocyte sedimentation rate $(\mathrm{ESR})^{2}$.

Our article was not an historical treatise on the ESR, but rather an examination of the utility of acute-phase reactants among patients with rheumatoid arthritis in the clinical trial setting. Therefore, as we made clear, we were concerned only with the ESR as proposed by Westergren, because this was the technique we used in our study. As far as we are aware, Westergren introduced it over 80 years ago, as we stated $1,3,4,5$. Parenthetically, based on work done at the end of the 1920s, the C-reactive protein was described by Tillett and Francis in $1930^{6}$.

Although not the subject of our article, with respect to recognition of attribution, we certainly agree with the comment by Kucharz ${ }^{7}$, repeated by Grzybowski and Sak, that the fact that Biernacki published in Polish and in German was likely a reason that his work has failed to be recognized by many. The comment that we read only the English-language literature is misplaced, presumptuous, and inaccurate. That aside, Kucharz writes that the original contributions of Biernacki in describing a method for erythrocyte sedimentation determination were published in 1894 (rather than 1897, as stated by Grzybowski and Sak) $7,8,9,10,11$.

ERIC L. MATTESON, MD, MPH; CYNTHIA S. CROWSON, MS, Mayo Clinic College of Medicine, 200 First Street SW, Rochester, Minnesota 55905, USA. Address correspondence to Dr. Matteson;

E-mail: matteson.eric@mayo.edu

\section{REFERENCES}

1. Crowson CS, Rahman MU, Matteson EL. Which measure of inflammation to use? A comparison of erythrocyte sedimentation rate and $\mathrm{C}$-reactive protein measurements from randomized clinical trials of golimumab in rheumatoid arthritis. J Rheumatol 2009;36:1606-10.
2. Grzybowski A, Sak JJ. Who discovered the erythrocyte sedimentation rate? [letter]. J Rheumatol 2011;38:1521-2.

3. Matteson EL, Rahman MU, Crowson CS. The story behind the acute-phase reactants [reply to letter]. J Rheumatol 2010;37:470

4. Westergren A. Studies of the suspension stability of the blood in pulmonary tuberculosis. Acta Med Scand 1921;54:247-82.

5. Westergren A. Die Senkungsreaktion. Allgemein-klinische Ergebnisse. Praktische Bedeutung bei Tuberkulose. Ergebn Inn Med Kinderheilk 1924;26:577-732.

6. Tillett WS, Francis T Jr. Serological reactions in pneumonia with a non-protein somatic fraction of pneumococcus. J Exp Med 1930;52:561-71.

7. Kucharz EJ. Edmund Biernacki and the erythrocyte sedimentation rate. Lancet 1987;329:696.

8. Kucharz EJ. 80e anniversaire de la decouverte du test de la vitesse de sedimentation sanguine. Mat Med Pol 1975;7:344-6.

9. Biernacki E. On the mural relation of erythrocytes to plasma in peripheral blood [Polish]. Gazeta Lek 1894;14:274-80.

10. Biernacki E. On the ratio of erythrocytes to plasma in blood, and the value of various methods of estimation of total erythrocyte volume [Polish]. Pamietnik Tow Lek (Warsaw) 1894;90:32-72.

11. Biernacki E. Ueber die Beziehung des Plasmas zu den rothen Blutkorperchen und ueber den Werth verschiedener Methoden der Blutkoerperchenvolumenbestimmung. Z Physiol Chem 1894;19:179-224.

J Rheumatol 2011;38:7; doi:10.3899/jrheum.101328 